\title{
Islamisasi Ilmu Pengetahuan Menurut Pandangan Syed Muhammad Naquib Al-Attas dan Implikasinya Terhadap Pengembangan PAI Di Perguruan Tinggi Umum
}

\author{
M. Sayyidul Abrori ${ }^{1 *}$, Muhammad Nurkholis ${ }^{2 \star *}$ \\ ${ }^{12}$ UIN Sunan Kalijaga Yogyakarta \\ *E-mail: abror.cafhalio@yahoo.com, ${ }^{* *}$ nurkholis102892@gmail.com
}

\begin{abstract}
Abstrak
This abstract contains aboutthe Islamic concept of science according to al-Attas that the biggest challenge facing Muslims isthe challenge of knowledge spread throughout the Islamic world by Western civilization.Islamization of knowledge means Islamizing or purifying Western product science which has been developed and used as a reference in the development discourselslamic education system in order to obtain a "typical Islamic" science. Al-Attas defines science as a meaning that comes into the soul along with the coming of the soul to the meaning and producing the desire and will of self. Al-Attas defines the meaning of education as a process of planting something into human beings and then affirms that something that is implanted is a science, and the purpose in seeking this knowledge is contained in the concept of ta'dib. While the aim of Islamic education is to instill virtue in "human self" as an individual and as part of society. Islamic education is capable Ideally, Naquib wants to print a good human being universally (al-insan al-kamil). The implication in the development of Islamic education in PTU is that Islamic education is directed at producing quality human resources, quality in the intellectual field and the most fundamental are moral and religious values.
\end{abstract}

Keywords: Islamization, Science, Development of PAI

\section{PENDAHULUAN}

Gagasan awal Islamisasi ilmu pengetahuan muncul pada saat konferensi dunia pertama tentang pendidikan muslim di Makkah, pada tahun 1977 yang diprakarsai oleh King Abdul Aziz University. Ide Islamisasi ilmu pengetahuan dilontarkan oleh Ismail Raji al-Faruqi dan Muhammad Naquib al-Attas. Menurut al-Attas bahwa tantangan terbesar yang dihadapi umat Islam adalah tantangan pengetahuan yang disebarkan keseluruh dunia Islam oleh peradaban Barat. Menurut alFaruqi bahwa sistem pendidikan Islam telah dicetak dalam sebuah karikatur Barat, dimana sains Barat telah terlepas dari nilai dan harkat manusia dan nilai spiritual dan harkat dengan Tuhan.

Bagi al-Faruqi, pendekatan yang dipakai adalah dengan jalan menuang kembali seluruh khazanah sains Barat dalam kerangka Islam, yaitu penulisan kembali buku-buku teks dan berbagai disiplin ilmu dengan wawasan ajaran Islam. Sedang menurut al-Attas adalah dengan jalan pertamapertama sains Barat harus dibersihkan dulu dari unsur-unsur yang bertentangan dengan ajaran Islam, kemudian merumuskan dan memadukan unsur Islam yang esensial dan konsep-konsep kunci sehingga menghasilkan komposisi yang merangkun pengetahuan inti.

Islamisasi pengetahuan berarti mengislamkan atau melakukan penyucian terhadap sains produk Barat yang selama ini dikembangkan dan dijadikan acuan dalam wacana pengembangan sistem pendidikan Islam agar diperoleh sains yang bercorak "khas Islami". Menurut Faisal, sains yang Islami harus meliputi iman, kebaikan dan keadilan manusia, baik sebagai individu dan sosial. Artinya sains yang berdasarkan keimanan dengan tujuan kemaslahatan manusia.

Islamisasi ilmu mewujudkan kemajuan pengetahuan mempunyai tujuan peradaban yang Islami dan masing-masing juga tidak menghendaki terpuruknya kondisi umat Islam di tengah-tengah akselerasi perkembangan kemajuan iptek. Dengan usaha gerakan Islamisasi ilmu pengetahuan ini diharapkan problem dikotomi keilmuan antara ilmu agama dan ilmu modern dapat dipadukan dan

\footnotetext{
${ }^{1}$ Mahasiswa Magister PAI UIN Sunan Kalijaga Yogyakarta

${ }^{2}$ Mahasiswa Magister PAI UIN Sunan Kalijaga Yogyakarta
} 
dapat diberikan secara integral dalam proses pendidikan.

Dalam perkembangannya, pendidikan Islam telah melahirkan dua polapemikiran yang kontradiktif. Keduanya mengambil bentuk yang berbeda, baik padaaspek materi, sistem pendekatan, atau dalam bentuk kelembagaan sekalipun, sebagai akumulasi dari respon dari sejarah pemikiran manusia dari masa ke masa terhadapadanya kebutuhan akan pendidikan. Dua model bentuk yang dimaksud adalahpendidikan Islam yang bercorak tradisionalis dan pendidikan Islam yang bercorak modernis. Pendidikan Islam yang bercorak tradisionalis dalam perkembangannyalebih menekankan pada aspek doktriner normatif yang cenderung eksklusif-literalis,apologetis. Sementara pendidikan Islam modernis, lama-kelamaan ditengarai mulai kehilangan ruh-ruh mendasarnya (Moh. Shofan, 2004: 6).

Pada dasarnya, pendidikan dalam perspektif Islam berupaya untuk mengembangkan seluruh potensi peserta didik seoptimal mungkin, baik yang menyangkut aspek jasmaniah, maupun rohaniah, akal dan akhlak. Dengan optimalisasi seluruh potensi yang dimiliknya, pendidikan Islam berupaya mengantarkan peserta didik ke arah kedewasaan pribadi secara paripurna, yaitu yangberiman dan berilmu pengetahuan (Samsul Nizar, 2001: vii).

Islam memandang peserta didik sebagai makhluk Allah dengan segala potensinya yang sempurna sebagai khalifah fil ardh, dan terbaik di antara makhluk lainnya. Kelebihan manusia tersebut bukan hanya sekedar fisik, tetapi lebih jauh dariitu, manusia memiliki kelebihan pada aspek psikisnya. Kedua aspek manusia tersebut memiliki potensinya masing-masing yang sangat mendukung bagi proses aktualisasidiri pada posisinya sebagai makhluk yang mulia. Dengan potensi fisik dan psikis,atau dengan kata lain potensi material dan spiritual tersebut menjadikan manusia sebagai makhluk ciptaan Allah yang terbaik (A. Susanto, 2009: 1).

Seperti diketahui, masalah pendidikan Islam merupakan masalah yang tidak akan pernah tuntas diwacanakan, tidak akan pernah rampung didesign, dan tidak akan pernah diperoleh solusi akhir, karena pendidikan Islam berkenaan dengan persoalan umat Islam dengan jumlah yang sangat besar, melebihi satu milyar, dengan pola kehidupan masing-masing yang sangat dinamis. Berbagai pemikiran dan solusi telah dikemukakan oleh para ahli, terutama menyangkut konsep dan implementasi konsep tersebut, yang sudah tentu bahwa warna-warni pemikirannya banyak dipengaruhi oleh pandangan hidup, nilai-nilai, dan pengalaman yang mereka lalui. Tetapi ada kesan kuat bahwa dalam satu hal mereka sepakat, bahwa pendidikan Islam harus bertujuan memberikan bekal dan pengembangan potensi keimanan, keislaman dankeihsanan. Selain itu, agar pendidikan Islam tidak mengabaikan pengembangan potensi jasmani, 'aqal, dan qalbunya secara seimbang dan integral, agar dia memiliki kesiapan menghadapi masa depannya dengan penuh percaya diri dan penuh tanggung jawab (Abdul Halim Soebahar, 2013: 5).

Pendidikan Islam bukan sekedar proses penanaman nilai-nilai moral untuk membentengi diri dari akses negatif globalisasi. Tetapi yang paling urgen adalah bagaimana nilai-nilai moral yang telah ditanamkan pendidikan Islam tersebut mampu berperan sebagai kekuatan pembebas (liberating force) dari himpitan kemiskinan, kebodohan, dan keterbelakangan budaya dan ekonomi. Kandungan materi pelajaran dalam pendidikan Islam yang masih berkutat pada tujuan yang lebih bersifat ortodoksi diakibatkan adanya kesalahan dalam memahami konsep-konsep pendidikan yang masih bersifat dikotomis, yakni pemilahan antara pendidikan agama dan pendidikan umum (sekular), bahkan mendudukkan keduanya secara diametral (Moh. Shofan, 2004: 5-6).

Menindaklanjuti masalah ini, salah satu tokoh pendidikan Islam yang sangat peduli terhadap eksistensi pendidikan Islam kontemporer, Syed Muhammad Naquib Al-Attas yang berdedukasi dipertengahan abad ke-20, merupakan otoritas yang sangat berpengaruh pada kebijakan Islam Melayu bahkan dunia internasional. Al-Attas bukan hanya seorang ideator ulung maupun hanya teoritis semata, namun Al-Attas telah merealisasikan dalam penerapan gagasan dan idenya pada Universitas (ISTAC) dan sukses dengan hasil yang patut dibanggakan.

\section{METODE/EKSPERIMEN}

Metode yang digunakan dalam artikel ini adalah library research dengan menggunakan pendekatan filosofis (untuk mengkaji Islamisasi IImu Pengetahuan Menurut Pandangan Syed Muhammad Naquib Al-Attas dan Implikasinya Terhadap Pengembangan PAI di Perguruan Tinggi Umum).

Teknik pengumpulan data yang penulis gunakan dalam artikel ini adalah teknik dokumentasi, yaitu mengumpulkan bahan berupa buku-buku yang ada di perpustakaan, artikel-artikel serta tulisantulisan yang berkaitan dengan penelitian, kemudian dikumpulkan dan diambil intisari yang berkaitan 


\section{Islamisasi Ilmu Pengetahuan Menurut Pandangan Syed Muhammad Naquib Al-Attas}

dengan objek kajian.

Analisis data dilakukan dengan menelaah berbagai literatur dari dokumentasi terhadap datadata hasil penelitian yang terkait dengan objek penelitian. Tahap pertama yang dilakukan adalah menganalisis dan identifikasi apa dan seperti apa masalah yang dikaji. Tahap kedua ialah pengkajian berbagai literatur dan data dokumentasi yang diperlukan untuk mencarikan solusi atas persoalan yang ditelaah. Tahap terakhir adalah menarik kesimpulan atas masalah yang dikaji.

\section{HASIL DAN PEMBAHASAN}

\section{A. Pemikiran Islamisasi IImu Pengetahuan Syed Muhammad Naquib Al-Attas}

Syed Muhammad Naquib Al-Attas dilahirkan di Bogor, Jawa Barat pada tanggal 5 September 1931 (Ramayulis dan Samsul Nizar, 2005: 118). Silsilah keluarganya bisa dilacak hingga ribuan tahun kebelakang melalui silsilah sayyid dalam keluarga Ba'alawi di hadramaut dengan silsilah yang sampai kepada Imam Hussein, cucu Nabi Muhammad SAW. Di antara leluhurnya ada yang menjadi wali dan ulama. Salah seorang di antara mereka adalah Syed Muhammad Al-„,Aydarus (dari pihak ibu), guru dan pembimbing ruhani syed Abu Hafs „Umar ba Syaiban dari Hadramaut, yang mengantarkan Nur Al-Din Al-Raniri, salah seorang alim ulama terkemuka di dunia Melayu, ke tarekat Rifa"iyah. Ibunda Syed Muhammad Naquib Al-Attas yaitu Syarifah Raquan Al-Ayadrus, berasal dari Bogor Jawa Barat, dan merupakan keturunan ningrat Sunda di Sukapura.

Latar belakang pemikiran Al-Attas terhadap tantangan-tantangan yang sedang dihadapi dunia pendidikan Islam dewasa ini, ternyata konsep pendidikan yang digagas Al-Attas adalah berusaha untuk menjawabnya. Al-Attas muncul pada era yang telah mengalami kemajuan zaman modern (canggih) yang nota bene seluruh aspek kehidupan telah berhubungan dan tersentuh oleh teknologi dan sains.

Melalui pandangan filosofisnya, Al-Attas telah berhasil mendiagnosa penyebab kemunduran umat Islam di zaman ini. Perspektif yang menyatakan bahwa hancurnya umat Islam bukan disebabkan karena kemunduran dibidang ekonomi, politik dan sebagainya. Namun persoalan yang lebih fundamental adalah kehancuran pada tingkatan metafisis, dimana umat Islam telah mengalami yang namanya corruption of knowledge (korupsi ilmu pengetahuan), keadaan inilah yang menyebabkan umat Islam kehilangan sebuah pijakan pada tradisi keilmuan yang gemilang tersimpan. Sehingga nilai adab dalam diri umat Islam dan jatuh pada kemerosotan yang sangat dalam.

Perlu kembali ditegaskan, bahwa tujuan mencari ilmu pengetahuan pada puncaknya adalah untuk menjadi manusia-manusia yang baik, dan bukan menjadi seorang warga negara yang baik, karena itu pendidikan mencerminkan manusia bukan negara. Menurut Islam, manusia seperti itu (insan al-kamil) itu telah ternyatakan pada diri Nabi Muhammad SAW.

Rumusan tujuan pendidikan Islam dewasa ini yang merupakan hasil tiruan dari Barat, ternyata tidak mampu menjawab persoalan-persoalan yang dihadapi pendidikan Islam. Menurut Al-Attas cara seperti itu tidak akan pernah berhasil mengingat tidak adanya model yang sempurna dan lengkap dari keteraturan yang yang lebih tinggi untuk dijadikan kriteria bagi perumusan ruang lingkup dan kandungannya, dan pada pendidikan sekuler gambaran mengenai manusia yang utuh memang tidak dimilikinya. Karena tujuan tertinggi pendidikan Islam adalah pembentukan manusia yang baik (insan kamil), maka puncak perwujudan dan kesempurnaan dalam pendidikan Islam adalah universitas, maka Al-Attas merumuskan skema antara manusia, pengetahuan, dan universitas sebagaimana dibawa ini:

Upaya yang dilakukan Al-Attas ini merupakan kelanjutan dari upaya yang telah dilakukan AlGhazali dalam konsep "ihya ulum ad-din" yang memulihkan kembali nilai adab, dan Al-Attas ini mengemukakannya kembali konsep tersebut pada zaman yang sudah modern ini. Zaman yang telah penuh dengan kontaminasi unsur sekuler dari Barat, dan upaya yang dilakukan pun tidak lain adalah upaya penanaman nilai-nilai Islam dengan ta"dib. Indikasi sederhananya berusaha bertindak dan bertingkah laku secara Islami. Oleh karena itu, wajar kalau pendidikan juga dapat diartikan sebagai upaya bimbingan atau tuntutan secara sadar oleh pendidik terhadap perkembangan jasmani dan rohani peserta didik menuju terbentuknya kepribadian utama (Zulkarnain, akses 13 April 2018).

a) Islamisasi IImu Pengetahuan Syed Muhammad Naquib Al-Attas

Al-Attas mendefinisikan ilmu sebagai sebuah makna yang datang ke dalam jiwa bersamaan dengan datangnya jiwa kepada makna dan menghasilkan hasrat serta kehendak diri (Syed Muhammad Naquib Al-Attas, 2017: 13). Dengan kata lain, hadirnya makna kedalam jiwa berarti Tuhan sebagai sumber pengetahuan, sedangkan hadirnya jiwa kepada makna menunjukkan bahwa jiwa sebagai penafsirnya.

Islamisasi ilmu tidak lain adalah Islamisasi ilmu pengetahuan kontemporer atau Islamisasi ilmu modern. Yang demikian ini karena ilmu-ilmu kontemporer dan modern lah yang dianggap telah

\section{Sayyidul Abrori ${ }^{1}$ dan Muhammad Nurkholis ${ }^{2}$}


mengalami sekularisasi, karena ilmu-ilmu tersebut ditemukan dan dikembangkan oleh peradaban Barat. Tidak benar jika dikatakan bahwa ilmu-ilmu tersebut dijamin universal dan bebas nilai. Syed Muhammad Naquib Al-Attas mengatakan,"Ilmu tidak bersifat netral. la bisa disusupi oleh sifat dan kandungan yang menyerupai ilmu.

Islamisasi ilmu pengetahuan diterangkan secara jelas oleh Al Attas, ialah pembebasan akal dan bahasa manusia dari magis, mitologis, animisme, nasionalisme buta, dan penguasaan sekularisme. Ini bermakna bahwa umat Islam semestinya memiliki akal dan bahasa yang terbebas dari pengaruh magis, mitos, animisme, nasionalisme buta dansekularisme. Islamisasi juga membebaskan manusia dari.sikap tunduk kepada keperluan jasmaninya yang cenderung menzhalimi dirinya sendiri, karena sifat jasmani adalah cenderung lalai terhadap hakikat dan asal muasal manusia. Dengan demikian, islamisasi tidak lain adalah proses pengembalian kepada fitrah (Wan Mohd Nor Wan Daud, 341).

Tujuan Islamisasi menurut Al-Attas adalah untuk melindungi umat Islam dari ilmu yang sudah tercemar dan dengan demikian menyesatkan. Sebaliknya, dengan ilmu seorang muslim diharapkan akan semakin bertambah keimanannya. Demikian pula, Islamisasi ilmu akan melahirkan keamanan, kebaikan dan keadilan bagi umat manusia.

Adapun pemikiran Naquib Al-Attas meliputi dua, yaitu:

1) Pandangan Tentang Epistimologi Islam

Al-Attas menjelaskan bahwa kemerosotan ilmu pengetahuan Islam terutama sekali berhubungan dengan epistemologi. Problem umat Islam muncul ketika sains modern diterima di negara-negara Muslim modern, di saat kesadaran epistemologis Muslim amat lemah. Padahal epistemologi sains modern berpijak pada landasan pemisahan agama dalam ilmu pengetahuan. Epistemologi Islam tidak berangkat dari keraguan (sebagaimana sains modern barat dikembangkan dengan berlandaskan kepadanya), melainkan berangkat dari keyakinan akanadanya kebenaran itu sendiri. Kebenaran yang secara inheren telah terkandung dalam al-Qur'an sebagai petunjuk Tuhan. Bagi Al-Attas sendiri, dalam proses pembalikan kesadaran epistemologis ini, program Islamisasi menjadi satu bagian kecil dari upaya besar pemecahan masalah epistimologi ilmu pengetahuan.

2) Pandangan tentang Dewesternisasi dan Islamisasi

Dewesternisasi adalah proses memisahkan dan menghilangkan unsur-unsur sekuler dari tubuh pengetahuan yang akan merubah bentuk-bentuk dan nilai-nilai dari pandangan konseptual tentang pengetahuan seperti yang disajikan saat ini. Yang pada dasarnya upaya tersebut merupakan bentuk usaha pemurnian ajaran Islam dari segala pengaruh barat. Upaya dewesternisasi ini sendiri tidak akan mempunyai signifikansi bagi umat Islam bila tidak dilanjutkan dengan gerakan Islamisasi. AlAttas mengoreksi disiplin ilmu-ilmu modern dan memurnikan ilmu-ilmu Islam yang telah tercelup dalam paham-paham sekuler. Perkembangan ilmu pengetahuan modern yang mengandung ideologi sekuralisme ini harus direformulasikan secara konseptual melalui Islamisasi ilmu pengetahuan agar tidak terlepas dari nilai-nilai spiritualitas dan transedensi ketuhanannya.

b) Konsepsi Pemikiran Pendidikan Syed Muhammad Naquib Al-Attas

1) Gagasan tentang manusia

Manusia adalah binatang rasional yang mengacu kepada nalar. Istilah nalar sendiri selaras dengan terma 'aql. Al-'aql sendiri pada dasarnya adalah ikatan atau simbol yang mengandung makna suatu sifat dalam menyimpulkan objek-objek ilmu pengetahuan dengan menggunakan sarana katakata. Dan dari sinilah timbul istilah al-Hayawanun Nathiq. Nathiq selain dimaknai rasio juga dimaknai sebagai "pembicaraan" (yakni suatu kekuatan dan kapasitas untuk merangkai simbol bunyi yang menghasilkan makna). Di samping mempunyai rasio, manusia juga mempunyai fakultas batin yang mampu merumuskan makna-makna (Dzu Nutq). Fakultas batin ini disebut-sebut sebagai hati, yaitu suatu substansi ruhaniyah yang dapat memahami dan membedakan kebenaran dari kepalsuan.

Manusia terdiri dari dua substansi, yakni jiwa dan raga, yang berwujud badan dan roh, atau dengan bahasa lain jasmaniyah dan ruhaniyah. Sebelum berbentuk jasmani, manusia telah mengikat janji akan mengakui Allah sebagai Tuhannya. Perjanjian suci (primordial) ini mempunyai konsekuensi selalu akan mengikuti kehendak Allah SWT (Fazlurrahman, 1981: 49). Dalam diri manusia sebenarnya ada potensi untuk beragama, dalam arti kepatuhak kepada Tuhan. Dan tidak ada kepatuhan (din) yang sejati tanpa adanya sikap penyerahan diri (Islam) (Nurcholis Majid, 1992: 41). Dengan berlandaskan kepada kepatuhan dan penyerahan diri, maka manusia akan mencapai kesadaran

2) Gagasan tentang Definisi dan Makna Pendidikan

Dalam Islam istilah pendidikan dikenal melalui tiga terma yaitu, tarbiyah, ta'dib dan ta'lim. AlAttas cenderung lebih memakai ta'dib dari pada istilah tarbiyah maupun ta'lim. Kata tarbiyah berarti mengasuh, menanggung, memberi makan, memelihara, menjadikan tumbuh, membesarkan dan menjinakkan. Sedangkan terma ta'lim, meskipun mempunyai makna yang lebih luas dari tarbiyah, 


\section{Islamisasi IImu Pengetahuan Menurut

yakni informasi, nasehat, bimbingan, ajaran dan latihan. Dari pengertian atas dua terma diatas, menurut Naquib, terma ta'diblah yang lebih cocok digunakan dalam pendidikan Islam. ta'dib berasal dari kata adaba yang mempunyai arti mendidik, kehalusan budi, kebiasaan yang baik, akhlak, kepantasan, kemanusiaan dan kasusastran. Dalam struktur konseptual, terma ta'dib sudah ('ilm), pengajaran (tarbiyah) (Naquib Al-Attas : 279-280).

Mencakup unsur-unsur pengetahuan (ta'lim) dan penyuluhan yang baik. Sebagaimana dalam pandangan Al-Attas bahwamasalah mendasar dalam pendidikan Islam selama iniadalah hilangnya nilai-nilai adab (etika) dalam arti luas. IImu tidak bisa diajarkan dan ditularkan kepada anak didik kecuali orang tersebut memiliki adab yang tepatterhadap ilmu pengetahuan dalam berbagai bidang. Inti dari pendidikan itu sendiri adalah pembetukan watak dan akhlak yang mulia. Dari sini Al-Attas mengartikan makna pendidikan sebagai suatu proses penanaman sesuatu kedalam diri manusia dan kemudian ditegaskan bahwa sesuatu yang ditanamkan itu adalah ilmu, dan tujuan dalam mencari ilmu ini terkandung dalam konsep ta'dib.

3) Gagasan tentang Tujuan Pendidikan

Al-Attas beranggapan bahwa tujuan pendidikan Islam adalah menanamkan kebajikan dalam "diri manusia" sebagai individu dan sebagai bagian dari masyarakat. Secara ideal, Naquib menghendaki pendidikan Islam mampu mencetak manusia yang baik secara universal (al-insan alkamil). Dalam hal ini, manusia yang baik yang dimaksud adalah individu yang beradab, bijak, mengenali dan sadar akan realitas sesuatu, termasuk posisi Tuhan dalam realitas itu. Suatu tujuan yang mengarah pada dua demensi sekaligus yakni, sebagai `abdullah (hamba Allah), dan sebagai khalifah fi al-ardh (wakil Allah di muka bumi). Dengan harapan yang tinggi, Al-Atas menginginkan agar pendidikan Islam dapat mencetak manusia paripurna, insan kamil yang bercirikan universalis dalam wawasan dan ilmu pengetahuan dengan bercermin kepada ketauladanan Nabi Muhammad SAW.

Pandangan baik, sesungguhnya Al-Attas tentang masyarakat yang tidak terlepas dari individuindividu yang baik. Jadi, salah satu upaya untuk mewujudkan masyarakat yang baik, berarti tugas pendidikan harus membentuk kepribadian masing-masing individu secara baik. Karena masyarakat merupakan bagian dari kumpulan individu-individu. Manusia yang seimbang pada garis vertikal dan horizontalnya. Lebih lanjut, menurutnya pendidikan Islam harus mengacu kepada aspekmoraltransedental (afektif) tanpa harus meninggalkan aspek kognitif (sensual logis dan psikomorik (sensual empirik).

4) Gagasan tentang Sistem Pendidikan Islam

Gagasan Al-Attas tentang sistem pendidikan Islam ini tidak bisa dilepaskan (terpisah) dari pemaknaannya terhadap konsep pendidikan. Sistem pendidikan Islam bagi Al-Attas haruslah mengandung unsur adab (etika) dan ilmu pengetahuan, karena inti dari pendidikan itu sendiri adalah pembetukan watak dan akhlak mulia manusia yang mampu mengembangkan ilmu pengetahuan yang bermanfaat bagi dirinya sendiri khususnya dan bagi umat manusia umumnya. Sistem pendidikan yang diformulasikannya adalah mengintegrasikan ilmu dalam sistem pendidikan Islam, artinya Islam harus menghadirkan dan mengajarkan dalam proses pendidikannya tidak hanya ilmuilmu agama, tetapi juga ilmu-ilmu rasional, intelek dan filosofis.

Namun ilmu pengetahuan dan teknologi harusterlebih dahulu dilandasi pertimbangan nilai-nilai dan ajaran agama. Karena secara makro dapat disimpulkan bahwa pendidikan Islam masih mengalami keterjajahan oleh konsepsi pendidikan Barat. IImu masih dipandang secara dikotomis, sehingga tidak ada integrasi ilmu yang seharusnya diwujudkan untuk mengembangkan ilmu pengetahuan yang berwawasan dan bernuansa Islami.

5) Gagasan tentang ilmu

Ilmu merupakan suatu sub sistem yang tidak dapat dipisahkan dari pendidikan Islam. Di mana al-Attas menyatakan: "pendidikan adalah upaya menanamkan sesuatu secara bertahap ke dalam diri manusia (Hasan Langgulung, 1987 : 238). Al-Attas mendefinisikan ilmu dari sudut epistimologi sebagai sampainya makna sesuatu pada jiwa dan sampainya jiwa pada makna sesuatu. Makna sesuatu di sini adalah maknanya yang benar, makna yang benar dalam konteks ini ditentukan oleh pandangan Islam tentang hakikat dari kebendaan sebagaimana yang diproyeksikan oleh sistem konseptual Al-Quran.

Al-Attas mengklasifikasi ilmu menjadi dua bagian: (1) fardu'ain yang memahaminya pemberian Allah yang mencakup di dalamnya ilmu-ilmu agama (Al-quran, as-sunnah, al-syariah, teologi, metafisika Islam atau tasawuf dan ilmu linguistic). (2) fardu kifayah yang memahami ilmu-ilmu capaian manusia yang meliputi ilmu-ilmu rasional, intelektual dan filosofis (ilmu kemanusiaan, alam, terapan, teknologi).

c) Implikasi Pengembangan PAI di Perguruan Tinggi Umum 
Islamisasi ilmu pengetahuan tidak cukup hanya menjadi sebuah kajian, publikasi dari hasil kajian merupakan langkah dalam menyebarluaskan Islamisasi ilmu pengetahuan ke pada masyarakat luas untuk dikenal. Menyebarkan karya-karya disiplin ilmu yang telah diislamisasikan melalui seminar atau dunia pendidikan adalah upaya agar hasil kajian tidak menjadi hal yang sia-sia.

Adapun Implikasi konsep ta'dib dalam pendidikan Islam yakni:

1) Menurut al-Attas, pada prinsipnya pendidikan itu bertujuan untuk melahirkan manusia yang baik, manusia adab atau Insan kamil yang beriman dan taqwa kepada Allah Swt sebagai khaliq sang penciptanya. Menurut Achmadi, insan kamil. Implikasinya dalam tujuan pendidikan Islam yakni tujuan pendidikan Islam diarahkan untuk menghasilkan sumber daya manusia yang bermutu, berkualitas dalam bidang intelektual dan yang paling mendasaradalah nilai-nilai moral-agama selalu membimbingnya.

2) Bangunan kurikulum pendidikan Islam, menurut al-Attas, berangkat dari pandangan bahwa karena manusia itu bersifat dualistik (Naquib al-Attas: 85), kandungan kurikulum pendidikan harus memenuhi dua aspek dasar manusia tersebut. Pertama, memenuhi kebutuhannya yang berdimensi permanen dan spiritual atau fardhu 'ain; dan kedua, yang memenuhi kebutuhan material-emosional atau fardhu kifayah. Implikasinya dalam merumuskan kurikulum

pendidikan Islam hendaknya bentuk dan formulasi kurikulum di sini harus mengandung makna dan nuansa nilai-nilai "ilahiyah" yang tidak mesti dipahami dalam bentuk dikotomis, yakni mengalokasikan pada satu bidang disiplin ilmu yang khusus dalam membahas mengenai masalah nilai. Akan tetapi proses sosialisasinya bisa didekati dengan muatan semua disiplin ilmu yang diajarkan dengan ruh dan semangat moralitas atau akhlak Islam.

3) Pada intinya Pendidikan dalam perspektif al-Attas (ta'dib) adalah proses penanaman adab. Dalam menyelesaikan permasalahan di atas ta'dib menempati relevansinya, karena dalam konteks metodologis dan pedagogis selain mengandung proses intelektualisasi,ta'dib juga mengandung proses inkulturisasi, proses pembudayaan anak didik dan orang-orang yang terlibat di dalam masyarakat berdasarkan nilai-nilai yang luhur. Implikasinya dalam metode pendidikan Islam, yakni metodologi pengajaran pendidikan lebih merupakan proses learning (proses pendidikan) ketimbang hanya proses teaching (proses pengajaran). Disampingproses intelektualisasi juga proses inkulturisasi.

\section{B. Pengembangan Pembelajaran PAl di Perguruan Tinggi Umum}

\section{a. PAl di Perguruan Tinggi Umum}

PAI menurut Zakiyah Darajat adalah usaha berupa bimbingan dan asuhan terhadap anak didik agar setelah selesai dari pendidikannya dapat memahami dan mengamalkan ajaran agama Islam serta menjadikannya sebagai pandangan hidup (way of life) (Zakiah Daradjat, $2008: 15$ ).

Eksistensi PAI di Perguruan Tinggi selain merupakan mata kuliah wajib, juga sangat berarti untuk mewujudkan tujuan pendidikan Nasional, khususnya aspek berakhlak mulia (Marzuki, 1997 : 93). Berdasarkan Undang-Undang Nomor 12 tahun 2012 tentang Pendidikan Tinggi, MKWU-PAI merupakan mata kuliah wajib yang diselenggarakan secara mandiri di setiap perguruan tinggi dan diberikan kepada semua mahasiswa yang beragama Islam di semua jenjang dan tingkatan serta diajarkan oleh para dosen profesional yang juga beragama Islam. Pada dasarnya, MKWU-PAI tidak untuk menjadikan mahasiswa sebagai ahli di bidang agama Islam, melainkan untuk menjadikan mereka semakin taat menjalankan perintah agama dengan baik dan benar

b. Status PAI di Perguruan Tinggi Umum

Eksistensi PAI di Perguruan Tinggi selain merupakan Mata Kuliah Wajib (MKWU), juga sangat berarti untuk mewujudkan tujuan pendidikan Nasional, khususnya aspek berakhlak mulia (Marzuki, 1997 : 93). Berdasarkan Undang-Undang Nomor 12 tahun 2012 tentang Pendidikan Tinggi, MKWUPAI merupakan mata kuliah wajib yang diselenggarakan secara mandiri di setiap perguruan tinggi dan diberikan kepada semua mahasiswa yang beragama Islam di semua jenjang dan tingkatan serta diajarkan oleh para dosen profesional yang juga beragama Islam. Pada dasarnya, MKWU-PAI tidak untuk menjadikan mahasiswa sebagai ahli di bidang agama Islam, melainkan untuk menjadikan mereka semakin taat menjalankan perintah agama dengan baik dan benar.

c. Tujuan PAI di PTU

Tujuan MKQWU PAI adalah meningkatnya pemahaman, penghayatan, dan pengamalan ajaran Islam secara komprehensif (kaffah) dalam pengembangan keilmuan, profesi, dan kehidupan bermasyarakat. Adapun secara spesifik tujuan MKWU-PAI adalah sebagai berikut.

1) Meningkatnya kualitas keimanan, ketakwaan, dan akhlak mulia mahasiswa.

2) Meningkatnya kualitas dan kuantitas pelaksanaan ibadah ritual (mahdhah) mahasiswa. 


\section{Islamisasi Ilmu Pengetahuan Menurut

3) Meningkatnya pengetahuan dan keterampilan mahasiswa dalam memecahkan problematika kehidupan dengan berlandaskan pada ajaran Islam.

4) Meningkatnya kematangan dan kearifan berpikir dan berperilaku mahasiswa dalam pergaulan global.

5) Meningkatnya pemahaman dan kesadaran mahasiswa dalam mengembangkan disiplin ilmu dan profesi yang ditekuninya, sebagai bagian dari ibadah (ghair mahdhah).

d. Ruang Lingkup PAI di Perguruan Tinggi Umum

Ruang lingkup materi pembelajaran MKWU-PAI meliputi beberapa topik. Setiap topik sekaligus merupakan pokok bahasan yang harus dielaborasi dan dikaji lebih lanjut memalui pendekatan activity base sejalan dengan Kompetensi Dasar (KD) masing-masing. Ruang lingkup tersebut adalah sebagai berikut.

1) Mengapa dan bagaimana mempelajari Islam di PerguruanTinggi?

2) Bagaimana manusiabertuhan?

3) Bagaimana agama menjaminkebahagiaan?

4) Bagaimana mengintegrasikan iman, Islam, dan insan dalam membentuk insankamil?

5) Bagaimana membangun paradigma Qurani untuk kehidupan Modern?

6) Bagaimana membumikan Islam dilndonesia?

7) Bagaimana Islam membangun persatuan dalamkeberagaman?

8) Bagaimana kontribusi Islam dalam pengembangan peradaban dunia?

9) Bagaimana Islam menghadapi tantanganmodernisasi?

10) Bagaimana fungsi dan peran masjid dalam pengembangan budaya Islam dikampus?

e. Proses Pembelajaran Pendidikan Agama Islam di Perguruan Tinggi Umum

Pembelajaran Pendidikan Agama Islam pada dasarnya menerapkan pendekatan berbasis proses keilmuan (scientific / epistemologic approach) dengan sintakmatik generiksebagai berikut.

1) Mengamati

2) Menanya

3) Mengumpulkaninformasi

4) Mengasosiasi

5) Mengkomunikasikan.

Pendekatan tersebut dapat dikemas dalam pelbagai model pembelajaran yang secara psikologis-pedagogis memiliki karakterpembelajaran yang mengaktifkan mahasiswa (student active learning) sebagai peserta didik sekaligus orang dewasa. Dengan pendekatan ini, mahasiswa difasilitasi untuk lebih banyak melakukan proses membangun pengetahuan (epistemological approaches) melalui transformasi pengalaman dalam berbagai model antara lain sebagai berikut.

1) Pembelajaran Berbasis Masalah (Problem-Based Learning/PBL): merupakan model pembelajaran yang menggunakan masalah yang kompleks dan nyata untuk memicu pembelajaran sebagai langkah awal dalam mengumpulkan dan mengintegrasikan pengetahuanbaru.

2) Projek Belajar Kewarganegaraan (Project Citizen): merupakan model pembelajaran pemecahan masalah kewargaanegaraan berbasis portfolio dengan fokus kajian masalah kehidupan masyarakat dari sudut pandang warga negara yang disajikan dalam bentuk simulasi dengar pendapat (simulated public hearing).

3) Studi Kasus (Case Study): merupakan model pembelajaran dengan cara memfasilitasi mahasiswa dengan suatu atau beberapa kasus, atau memilih kasus baru untuk dicari pemecahannya sesuai dengan kompetensi dasar yang sedang dibahas.

4) Kerja lapangan (Work Experiences / Service Learning): merupakan model pembelajaran yang memusatkan perhatian pada bahan kajian yang terkait langsung dengan kompetensi dasar yang dipelajari di luar kampus (extra-muralactivities)

5) Tugas kelompok (Syndicate Group): merupakan model pembelajaran dengan pemberian tugas kepada kelompok mahasiswa berdasarkan minat dengan fokus tugas tertentu dalam rangka menyusun rekomendasi dalam bentuk makalah yang akan disajikan dalam suatuforum.

6) Debat (Controversial Issues): merupakan model pembelajaran yang memusatkan perhatian pada pengembangan kemampuan berpikir dan berkomunikasi secara kritis dan produktif.

7) Simulasi (Simulation): merupakan model pembelajaran dengan tujuan penguasaan substansi melalui pengembangan imajinasi dan penghayatan, seperti memerankan seorang tokoh.

8) Pembelajaran Kolaboratif (Collaborative Learning): merupakan model pembelajaran berbentuk proses belajar kelompok yang memberi peluang kepada setiap anggota untuk menyumbangkanpemikiran dan / atau pengalaman, untuk secara bersama-sama saling 
meningkatkan penguasaan kompetensi dasar.

9) Bola Salju Menggelinding (Snow-balling Process): merupakan model pembelajaran melalui pemberian tugas individual, kemudian berpasangan. Selanjutnya dicarikan pasangan yang lain sehingga semakin lama anggota kelompok semakin besar seperti bola salju yang menggelinding.

Sementara itu, Sutrisno menambahkan dua strategi lainnya, yaitu SGD (Small Group Discussion) dan DL (Discovery Learning), dan SDL(Self Discovery Learning). SDL merupakan proses belajar yang dilakukan atas inisiatif individu mahasiswa sendiri dan dilakukan di luar jam perkuliahan.

f. Penilaian MKWU PAI di Perguruan Tinggi Umum

Adapun konsep penilaian MKWU PAI di PTU adalah sebagai berikut.

1) Penilaian hasil belajar mahasiswa dilakukan berdasarkan data yang di peroleh melalui penugasan dan observasi kinerja mahasiswa melalui tampilan lisan atautertulis.

2) Kriteria penilaian dan pembobotannya diserahkan kepada dosen pengampu dan disesuaikan dengan pedoman evaluasi akademik yang berlaka pada perguruan tinggimasing-masing.

3) Sistem penilaian dijelaskan kepada mahasiswa pada awal perkuliahan.

4) Evaluasi Pendidikan Agama Islam dilaksanakan terhadap hasil penugasan-penugasan dan kinerjamahasiswa.

5) Sejalan dengan poin 2, bobot nilai evaluasi diserahkan kepada dosen pengampu dan disesuaikan dengan pedoman evaluasi akademik yang berlaku pada perguruan tinggimasing-masing.

6) Dosen Pendidikan Agama Islam dapat mengembangkan sendiri jenis-jenis evaluasi sesuai dengan prinsip pembelajaran berbasis kompetensi, situasi, dan kondisimasing-masing. (Sutrisno \& Suyadi, $2016: 147$ )

g. Model Pengembangan PAl di perguruan Tinggi Umum

Menurut Muhaimin, terdapat tiga model pengembangan PAI sebagai berikut.

1) Model Dikotomis

Pada model ini, aspek kehidupan dipandang sangat sederhana. Implikasinya adalah PAI yang hanya berkisar pada aspek ukhrowi yang terpisah dengan aspek kehidupan duniawi. PAI hanya mengurusi persoalan ritual dan spiritual, sementara kehidupan ekonomi, sosial, politik, seni budaya, ilmu pengetahuan teknologi hanya dianggap sebagai urusan duniawi yang menjadi bidang garapan non-agama.

2) Model Mekanisme

Model ini memandang bahwa kehidupan terdiri dari banyak aspek, dan pendidikan dipandang sebagai penanaman dan pengembangan seperangkat nilai kehidupan (nilai agama, nilai individu, nilai sosial politik ekonomi, nilai rasional, esteika, dan sebagainya), yang masing-masing berjalan dan bergerak menurut fungsinya. Hubungan antara nilai agama dengan nilai-nilai lainnya dapat bersifat horizontal-lateral (independent), latered-sekuensal, atau vertical linier (Muhaimin, 2009 : 59-71).

3) Model Sistemik (Organism)

Model ini bertolak pada pandangan bahwa aktifitas kependidikan merupakan suatu sistem yang terdiri atas komponen-komponen yang hidup bersama dan bekerja sama secara terpadu menuju tujuan tertentu, yaitu terwujudnya kehidupan yang religius atau dijiwai oleh ajaran dan nilainilai agama. Pandangan semacam ini menggarisbawahi pentingnya kerangka pemikiran yang dibangun dari fundamental doctrines dan fundamental values yang tertuang dalam sumber ajaran pokok Islam, yaitu al-Quran dan al-Sunnah.

\section{TEMUAN ARTIKEL}

Implementasi pengilmuan Islam Syed Muhammad Naquib Al-Attas dalam pengembangan PAI di Perguruan Tinggi Umum diejawantahkan dalam bentuk Islamisasi IImu Pengetahuan. Seperti disebutkan di atas, pembelajaran PAI di PTU perlu dikembangkan sedemikian rupa agar tetap eksis dan memberikan kontribusi nyata pada era sekarang ini. Salah satunya adalah pengembangan dengan konsep Islamisasi IImu Pengetahuan. Sehingga bisa dikatakan bahwa dengan konsep Islamisasi IImu Pengetahuan dalam pengembangan pembelajaran PAl termasuk dalam model pengembangan sistemik.

Secara sederhana, pengembangan pembelajaran PAI dengan Konsep Islamisasi IImu Pengetahuan adalah sebagai berikut.

1. Aspek Tujuan Pembelajaran

Tujuan pembelajaran PAI di PTU hendaknya berlandaskan tiga asas pemikiran Al-Attas tentang Islamisasi Ilmu Pengetahuan, yaitu Tarbiyah, Ta'dib dan Ta'lim.

2. Aspek Ruang Lingkup (Materi) 


\section{Islamisasi Ilmu Pengetahuan Menurut Pandangan Syed Muhammad Naquib Al-Attas}

Dalam askpek ini yang perlu disoroti adalah pengembangan materi PAI.

a. Asas Tarbiyah

pada prinsipnya pendidikan itu bertujuan untuk melahirkan manusia yang baik, manusia adab atau Insan kamil yang beriman dan taqwa kepada Allah Swt sebagai khaliq sang penciptanya. (insan kamil).

Implikasinya dalam tujuan pendidikan Islam yakni tujuan pendidikan Islam diarahkan untuk menghasilkan sumber daya manusia yang bermutu, berkualitas dalam bidang intelektual dan yang paling mendasar adalah nilai-nilai moral-agama selalu membimbingnya.

b. Asas Ta'dib

Pada intinya Pendidikan dalam perspektif al-Attas (ta'dib) adalah proses penanaman adab. Dalam menyelesaikan permasalahan di atas ta'dib menempati relevansinya, karena dalam konteks metodologis dan pedagogis selain mengandung proses intelektualisasi, ta'dib juga mengandung proses inkulturisasi, proses pembudayaan anak didik dan orang-orang yang terlibat di dalam masyarakat berdasarkan nilai-nilai yang luhur. Implikasinya dalam metode pendidikan Islam, yakni metodologi pengajaran pendidikan lebih merupakan proses learning (proses pendidikan) ketimbang hanya proses teaching (proses pengajaran). Disampingproses intelektualisasi juga proses inkulturisasi.

c. Asas Ta'lim

Bangunan kurikulum pendidikan Islam, menurut al-Attas, berangkat dari pandangan bahwa karena manusia itu bersifat dualistik, kandungan kurikulum pendidikan harus memenuhi dua aspek dasar manusia tersebut. Pertama, memenuhi kebutuhannya yang berdimensi permanen dan spiritual atau fardhu 'ain; dan kedua, yang memenuhi kebutuhan material-emosional atau fardhu kifayah. Implikasinya dalam merumuskan kurikulum pendidikan Islam hendaknya bentuk dan formulasi kurikulum di sini harus mengandung makna dan nuansa nilai-nilai "ilahiyah" yang tidak mesti dipahami dalam bentuk dikotomis, yakni mengalokasikan pada satu bidang disiplin ilmu yang khusus dalam membahas mengenai masalah nilai. Akan tetapi proses sosialisasinya bisa didekati dengan muatan semua disiplin ilmu yang diajarkan dengan ruh dan semangat moralitas atau akhlak Islam.

3. Aspek Proses Pembelajaran

Proses atau metode pembelajaran hendaknya memerhatikan asas dasar tersebut. Seperti dalam memilih strategi dan metode pembelajaran, termasuk dalam menentukan media pembelajaran.

a. Asas Tarbiyah

Strategi dan metode yang digunakan hendaknya memerhatikan sisi kemanusiaan mahasiswa. Sehingga perlu dipilih strategi dan metode yang di dalamnya dosen dan mahasiswa berinteraksi dengan baik. Selain itu, perlunya metode dan strategi yang mampu mengangkat eksistensi mahasiswa, seperti diskusi, problem based learning, dan sebagainya.

b. Asas Ta'dib

Perlunya kreasi dan inovasi dalam metode dan strategi pembelajaran. Sehingga tidak melulu metode ceramah dalam suatu pembelajaran, misalnya.

c. Asas Ta'lim

Misalnya, gambar pemain bola auratnya dibuat blur, atau menyebutkan si Fulan untuk menyebutkan seseorang yang akan diceritakan aibnya, dan sebagainya.

4. Aspek Penilaian

a. Asas Tarbiyah

Penilaian hendaknya memberikan porsi yang lebih terhadap penilaian sikap, tentunya tanpa mengesampingkan penilaian pengetahuan dan keterampilan. Mahasiswa perlu dinilai layaknya ia sebagai manusia.

b. Asas Ta'dib

Perlunya pemahaman bagi mahasiswa bahwa nilai angka bukanlah patokan dalam kesuksesan. Tapi ia merupakan faktor dari berbagai macam faktor yang menentukan kesuksesan.

c. Asas Ta'lim

Perlunya pemahaman bagi mahasiswa bahwa penilaian oleh dosen tidak sedetail penilaian oleh Tuhan. Oleh karena itu, jangan terlalu terpaku pada hasil penilaian oleh dosen

\section{PENUTUP}

Islamisai ilmu pengetahuan merupakan terobosan baru dari Pemikiran Syed Muhammad Naquib Al-Attas tentang pengilmuan Islam yang memberikan harapan bahwa Islam dan ilmu pengetahuan bisa saling berjalan beriringan. Dengan tiga metodenya, tarbiyah, ta'dib dan ta'lim, pengilmuan Islam menghendaki tranformasi sosial muslim, khususnya muslim di Indonesia. Tarbiyah maksudnya adalah semangat ilmu-ilmu pendidikan yang diidealkan oleh Islam. Ta'dib adalah semua 
keilmuan berlandaskan tata cara yang baik. Adapun ta'lim berarti ajaran dari orang beriman yang terbuka untuk semua orang.

Paradigma Islamisasi ilmu pengetahuan diejawantahkan dalam tiga asas dasar, yaitu Tarbiyah, Ta'dib, Ta'lim. Pembelajaran PAI di PTU bisa dikembangkan dengan ketiga asas tersebut. Sehingga, setiap aspek pembelajaran PAI (tujuan, materi, proses dan penilaian), dikembangkan berdasarkan asas tersebut. Misal, dalam aspek materi asas tarbiyah, maka disuahakan setiap materi mengandung dalil naqli, dan seterusnya. Dengan demikian, PAl di PTU bisa senantiasa dikembangkan tetapi tetap memiliki landasan islamiah yang kokoh, yaitu Tarbiyah (Pendidikan), Ta'dib (adab), dan Ta'lim(Pembelajaran).

\section{UCAPAN TERIMAKASIH}

Peneliti mengucapkan terimakasih kepada UIN Sunan Kalijaga Yogyakarta, LPPM STKIP Nurul Huda Sukaraja OKU Timur Dan Tim Jurnal Al I'tibar Program Studi Pendidikan Agama Islam STKIP Nurul Huda.

\section{DAFTAR PUSTAKA}

Abdul Halim Soebahar, Kebijakan Pendidikan Islam dari Ordonansi Guru sampai UU Sisdiknas, (Jakarta: PT RajaGrafindo Persada, 2013), cet ke-1.

Abdur Rahman Assegaf, Pendidikan Islam di Indonesia, (Yogyakarta: Suka Press, 2007), cet. ke-1.

Arifin, IImu Pendidikan Islam : Tinjauan Teoretis dan Praktis Berdasarkan Pendekata Interdisipliner, (Jakarta: PT Bumi Aksara, 2003), cet ke-1.

A. Fatah Yasin, Dimensi-dimensi Pendidikan Islam, (Yogyakarta: UIN Malang Press, 2008), cet ke-1, hlm. iii-iv.

A. Susanto, Pemikiran Pendidikan Islam, (Jakarta: AMZAH, 2009), cet ke-1.

Fazlurrahman, Major Themes of the Quran, Terj. Anas Mahyuddin, (Bandung: Pustaka, 1981).

Hasan Langgulung, Asas-asas Pendidikan Islam, (Jakarta:pistaka al- Husna, 1987)

http://spada.ristekdikti.go.id//ms1/mod/resource/view.php?id=10661, diakses pada Senin, 23 April 2018, 07.40 WIB.

Jalaludin, Teologi Pendidikan, (Jakarta: PT RajaGrafindo Persada, 2002), cet. ke-2.

Marzuki, "Pendidikan Agama Islam di Perguruan Tinggi Umum dan Pemberdayaan Masyarakat Indonesia", Jurnal, Cakrawala Pendidikan, no. 1, tahun XVI, 1997.

Mohammad Tidjani Djauhari, Pendidikan untuk Kebangkitan Islam, (Jakarta: TAJ, 2008), cet. ke-1.

Moh. Shofan, Pendidikan Berparadigma Profetik : Upaya Konstruktif Membongkar Dikotomi Sistem Pendidikan Islam, (Jawa Timur: UMG Press, 2004), cet ke-1.

Muhaimin, Rekonstruksi Pendidikan Islam: Dari Paradigma Pengembangan Manajemen Kelembagaan, Kurikulum Hingga Strategi Pembelajaran, (Jakarta: PT Raja Grafindo Persada, 2009)

Nurcholis Majid , Islam Doktrin Dan Peradaban:Sebuah Telaah Kritis Tentang Masalah Keimanan, Kemanusian Dan Kemodernan, (Jakarta: yayasan wakaf paradigma, 1992).

Ramayulis dan Samsul Nizar, Ensiklopedia Tokoh Pendidikan Islam, (Jakarta: PT Ciputat Press, 2005).

Samsul Nizar, Dasar-Dasar Pemikiran Pendidikan Islam, (Jakarta: Gaya Media Pratama, 2001), cet ke-1.

Sutrisno dan Suyadi, Desain Kurikulum Perguruan Tinggi: Mengacu pada Kurikulum Kualifikasi Nasional Indonesia, (Bandung: Remaja Rosdakarya, 2016).

Syed Muhammad Naquib al-Attas, Tinjauan Ringkas Peri Ilmu dan Pandangan Alam, (Pulau Pinang: Penerbit Universiti Sains Malysia, 2007).

Wan Mohd Nor Wan Daud, Filsafat dan Praktik Pendidikan Islam Syed Muhammad Naquib Al-Attas, (Bandung: Mizan, 2003), cet. ke-1.

Zakiah Daradjat, IImu Pendidikan Islam, (Jakarta: RajaGrafindo Persada, 2008).

Zuhairini, Filsafat Pendidikan Islam, (Jakarta: Bumi Aksara, 2009), cet ke-5.

Zulkarnain Ar, Pendidikan Islam Menurut Syekh Muhammad Naquib Al-Attas, dalam http://andeskopraya.blogspot.com, 13 April 2018. 